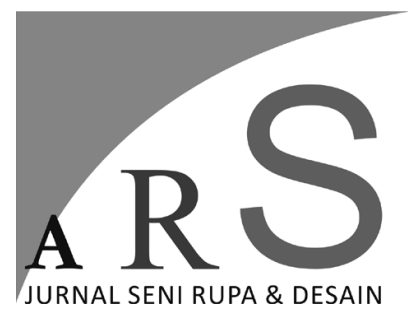

Volume 22 Nomor 1 - April 2019

\title{
MANAJEMEN STRATEGI PADA PENGELOLAAN KERSAN ART STUDIO
}

\author{
Meita Anggi Pangesti \\ Program Studi Tata Kelola Seni, \\ Fakultas Seni Rupa, Institut Seni Indonesia Yogyakarta
}

\begin{abstract}
ABSTRAK
Penelitian tentang Manajemen Strategi pada Pengelolaan Kersan Art Studio bertujuan untuk mengidentifikasi strategi yang sesuai untuk Kersan Art Studio. Sangat penting bagi Kersan Art Studio untuk memiliki perencanaan strategi jangka panjang agar tetap mampu bertahan di dunia seni rupa. Selain itu, penelitian ini juga mengidentifikasi faktor internal dan eksternal dalam upaya mendapatkan formulasi strategi yang sesuai untuk Kersan Art Studio. Metode penelitian yang digunakan dalam penelitian ini adalah kualitatif deskriptif dengan teknik pengumpulan data yang terdiri dari dua poin yaitu pengumpulan data primer dan data sekunder dengan melihat pengelolaan Kersan Art Studio untuk mengetahui dua faktor yaitu, faktor internal (kekuatan, kelemahan) dan faktor eksternal (peluang, ancaman), kemudian dianalisis menggunakan teknik analisis SWOT. Penelitian ini menghasilkan; (1) Berdasarkan Matrik IFAS dan EFAS pengelola Kersan Art Studio merespon dengan baik faktor internal dan eksternal yang dimiliki. (2) Berdasarkan kuadaran analisis SWOT pengelolaan Kersan Art Studio berada pada posisis kuadran I dengan arah kebijakan strategi agresif. Strategi yang harus diterapkan dalam kondisi ini adalah mendukung kebijakan pertumbuhan yang agresif (growth oriented strategy) yang diwujudkan dalam bentuk pengembangan pasar, integrasi horizontal dan integrasi ke belakang (3) Berdasarkan matrik SWOT, pengelolaan Kersan Art Studio Kersan memiliki peluang dan kekuatan sehingga dapat melakukan percepatan pengembangan dengan memaksimalkan posisi peluang dan kekuatan untuk meminimalisir kelemahan dan ancaman, posisi tersebut mengarah pada strategi SO.
\end{abstract}

Kata Kunci : formulasi strategi, Kersan Art Studio, analisis SWOT

\begin{abstract}
The research concerning Strategic Management in Kersan Art Studio purports to identify a good strategy for Kersan Art Studio. It is urgent for Kersan Art Studio to have proper long term planning in order to survive in Art world. Besides, this research also purports to identify internal as well external factors in attempt to formulate strategy applicable to Kersan Art Studio. Research method chosen is descriptive-qualitative using data collection method covering both points i.e. primary and secondary data and taking into consideration the management of Kersan Art Studio to discover two factors namely internal factor
\end{abstract}


(strength, weakness) and external factors (opportunities, threat), and perform analysis based on SWOT technique. The result of the research indicates: (1) according to matrix IFAS and EFAS the management of Kersan Art Studio responds well to internal and external factor. (2) According to SWOT quadrant analysis the management of Kersan Art Studio lies within quadrant 1 position with aggressive strategic policy. Strategy that must be applied in this circumstance can be materialized into developing market, horizontal integration and backward integration. (3) According to SWOT matrix, the management of Kersan Art Studio has both opportunities and strength to quicken development progress based on the current advantageous position and strength to minimize weakness and threat, and said position leans toward SO strategy.

Keywords: strategic formulation, Kersan Art Studio, SWOT analysis

\section{Pendahuluan}

Dunia seni telah mengalami banyak perkembangan, khususnya dunia seni rupa. Yogyakarta selain disebut sebagai kota pelajar dan kota budaya, juga merupakan salah satu kota tempat berkembangnya seni rupa di Indonesia. Sebagai tempat perkembangan seni rupa, keberadaan ruang seni sangat penting untuk menjadi wadah bagi seniman serta mendukung aktivitas berkeseniannya. Ruang seni merupakan salah satu medium penting dalam proses apresiasi karya seni kepada publik seni. Wacana tentang ruang seni banyak dibicarakan di berbagai kesempatan sejak beberapa dekade terakhir. Pembahasan tentang ruang seni telah menjadi wacana dalam perhelatan di pentas seni rupa Indonesia yaitu ketika terjadi boom seni lukis di era 80-an dan 90-an, di era boom seni rupa tahun 80 -an arti keberadaan ruang seni menjadi isu luas dikalangan seni rupa Indonesia. Sejumlah galeri swasta mulai bermunculan di kota-kota besar di Indonesia seperti, Jakarta, Bali, Yogyakarta, dan Bandung. (Sucitra, 2012:1)

Kemudian wacana tentang ruang seni kembalimencuat ditahun90-ansaatbangkitnya berbagai "ruang seni non-galeri" yang sering juga disebut sebagai ruang seni alternatif. Kemunculan ruang seni alternatif ini sebagai akibat dari keformalan dan ketidakmampuan galeri milik pemerintah maupun swasta untuk mengakomodasi gagasan-gagasan seniman. Pada boom seni rupa tahun 2000-an memicu tumbuh lebih banyaknya ruang seni yang diinisiasi seniman. Salah satu ruang seni yang muncul dari inisiasi seniman untuk membuka ruang seni pribadinya "studio" menjadi sebuah ruang seni terbuka adalah Kersan Art Studio, yang didirikan pada tahun 2009 oleh Lenny Ratnasari Weichert yang merupakan seniman alumni dari Institut Seni Indonesia Yogykarta. Konsep Kersan Art Studio adalah menjadi ruang terbuka untuk seni, kehidupan dan pendidikan. Program-program residensi disertai dengan kegiatan-kegiatan seperti workshop dan diskusi, yang bertujuan untuk memperkenalkan seni ke masyarakat umum. Kersan Art Studio berperan sebagai 'studio', dalam hal ini lebih menekankan pada proses dan ruang seni yang terbuka dimana menjadi ruang komunikasi antara seniman, kurator, penulis, akademisi. Kersan Art Studio berfokus pada pameran, proyek seni, musik, diskusi seni, pertukaran seniman dan residensi.

Selain dipicu dampak dari boom seni rupa, penciptaan ruang seni baru bagi seniman dan aktivis seni juga bisa dimaksudkan sebagai ruang apresiasi dengan seniman lain dan masyarakat seni. Kemunculan ruangruang seni baru juga bisa dijadikan sebagai sarana untuk mendekati publik agar lebih mengenal tentang dunia seni. Melihat semakin banyaknya kemunculan ruangruang seni baru khususnya di Yogyakarta dapat diartikan bahwa dunia seni rupa saat ini masih membutuhkan ruang-ruang baru untuk segala bentuk keseniannya, namun 
banyak ruang seni yang dihadirkan belum sesuai dengan fungsi yang direncanakan, sehingga menyebabkan tumbangnya eksistensi galeri pada kancah seni rupa di Yogyakarta pada aspek-aspek tertentu sangat terkorelasi dengan berperan aktifnya studiostudio sebagai efek dari dihadirkannya ruang pamer alternatif. (Jusmani, 2014)

Banyaknya galeri dan ruang seni yang gagal mempertahankan eksistensinya di dunia seni rupa, salah satunya dikarenakan tidak adanya rencana atau strategi jangka panjang untuk mempertahankan keberlangsungan lembaga tersebut. Melihat banyaknya galeri seni rupa yang tidak mampu mempertahankan eksistensinya di dunia seni rupa, galeri atau organisasi seni perlu adanya pengelolaan secara mendalam serta menyepakati arahan, sasaran, dan program jangka panjangnya agar ruang-ruang seni publik ini dapat berfungsi sesuai dengan peranannya di tengah perkembangan dunia seni rupa saat ini. Perencanaan strategi bagi organisasi atau perusahaan sangat dibutuhkan, dalam perencanaan strategi sebuah organisasi atau perusahaan strategi serta membuat keputusan mengenai pengalokasian sumber daya untuk menjalankan strategi tersebut.

Fenomena seniman membangun ruang seni seperti halnya Kersan Art Studio yang merupakan organisasi nonprofit lebih menarik untuk dibaca, karena kebutuhan akan adanya ruang seni yang cocok bagi seniman untuk melakukan kegiatan berkeseniannya dirasakan sendiri oleh seniman tersebut. Menurut Sumartono dalam Arya Sucitra, wacana seni rupa memerlukan keterlibatan ilmu-ilmu bantu secara lebih aktif, dengan cara pandang yang lebih luas melalui sudut pandang yang berbeda maka akan dapat menangkap nilainilai kritis terhadap kemunculan suatu fenomena seni. (2012) Seperti halnya melihat perkembangan dunia seni dari sudut pandang ilmu manajemen.

Sebagai sebuah ruang seni, Kersan Art Studio membutuhkan perencanaan strategi yang sesuai dengan organisasi agar dapat terus bertahan dan semakin berkembang sehingga mampu bersaing di tengah perkembangan pasar seni rupa saat ini. Pada penelitian ini berfokus pada manajemen strategi seperti apa yang sesuai untuk Kersan Art Studio saat ini untuk mempertahankan eksistensinya di dunia seni rupa.

\section{Rumusan Masalah}

Bagaimana pengelolaan dan perencanaan strategi pengembangan Kersan Art Studio?

\section{Tujuan Penelitian}

1. Mengetahui pengelolaan Kersan Art Studio.

2. Mengetahui faktor internal dan eksternal yang mempengaruhi pengelolaan Kersan Art Studio.

3. Mengetahui perencanaan strategi yang sesuai untuk Kersan Art Studio.

\section{Metode Penelitian}

1. Jenis Penelitian

Penelitian ini menggunakan pendekatan kualitatif deskriptif dengan metode atau pendekatan studi kasus, penelitian ini memusatkan diri secara intensif terhadap satu objek tertentu dengan cara mempelajari sebagai suatu kasus. Berbagai unit sosial dapat diselidiki secara intensif, baik secara menyeluruh maupun mengenai aspek-aspek tertentu yang mendapat perhatian khusus. (Zulnaidi, 2007:13)

2. Objek dan Lokasi Penelitian

Objek penelitian ini adalah pengelolaan di Kersan Art Studio sedangkan lokasi penelitian terletak di Jln. AS. Samawaat no 154, dusun Kersan, Tirtonirmolo, Kasihan, Bantul, Yogyakarta.

3. Subjek Penelitian

Subjek dari penelitian ini adalah pegawai dari Kersan Art Sudio serta orangorang yang tergabung dalam Yayasan Seni Kersan Indonesia sebagai lembaga yang menaungi dan mengelola seluruh kegiatan yang dilakukan oleh Kersan Art Studio. 


\section{Variabel Penelitian}

Variabel penelitian adalah setiap gejala yang diamati dan menjadi fokus penelitian. (Yaniawati \& Poppy, 2014:12) Variabel dalam penelitian ini ada gejala atau fenomena yang didapatkan dari pengamatan peneliti dalam pengelolaan Kersan Art Studio selama ini.

\section{Teknik Pengumpulan Data}

Penelitian ini menggunakan beberapa teknik pengumpulan data diantaranya adalah (1) Wawancara, yaitu pengumpulan data dengan langsung mengadakan tanya jawab kepada subjek yang diteliti. (2) Observasi, yaitu cara pengumpulan data dengan melihat langsung ke lapangan terhadap objek yang diteliti. Observasi difokuskan sebagai upaya mengumpulkan data dan informasi dari sumber data primer dengan mengoptimalkan pengamatan peneliti (3) Kuesioner, untuk mendapatkan penilaian terkait faktor kekuatan, kelemahan, peluang, dan ancaman pada pengelolaan Kersan Art Studio maka dilakukan pengisian kuesioner, pembobotan yang diisi oleh responden yang dinilai ahli dan memiliki informasi mendalam terkait dengan objek penelitian. Nilai dari proses pembobotan akan dimasukkan dalam penghitungan matrik IFAS (Internal Factor Analysis Summary) dan EFAS (External Factor Analysis Summary). Data numerik yang dihasilkan selanjutnya akan dianalisis untuk mengetahui kebijakan manajemen strategi yang sesuai bagi Kersan Art Studio. (4) Studi Pustaka, pengumpulan data dengan menggunakan sebagian atau seluruh data yang telah ada dari peneliti sebelumnya. Pengumpulan data dengan melihat dokumen-dokumen dari Kersan Art Studio baik dalam bentuk web, buku, booklet, dan rekaman audio visual.

\section{Metode Analisis Data}

Metode analisis data pada penelitian ini akan menggunakan dua metode analisis yaitu menggunakan analisis kualitatif secara deskriptif dan analisis SWOT. Metode analisis kualitatif deskriptif digunakan untuk memaparkan data-data yang ditemukan di lapangan kemudian data akan dianalisis secara kualitatif, baik itu yang berasal dokumentasi, rekaman arsip, wawancara, serta observasi langsung. Dari berbagai teknik pengumpulan data tersebut akan didapatkan sebuah data yang akan dianalisis berdasarkan atas kerangka pemikiran yang telah ada sebelumnya. Kerangka pemikiran tersebut merupakan desain awal yang merefleksikan serangkaian pertanyaan penelitian yang dibangun, tindakan review yang dilakukan terhadap literatur, dan pemahaman-pemahaman baru yang tercipta. Data-data tersebut selanjutnya akan dianalisis berdasarkan pada kerangka konsep dalam penelitian ini. Kemudian data yang diperoleh dianalisis menggunakan analisis SWOT yang merupakan singkatan dari strengths (kekuatan), weaknesses (kelemahan), opportunities (peluang), threats (ancaman), dimana SWOT ini dijadikan sebagai suatu model dalam menganalisis suatu organisasi yang berorientasi profit dan non-profit dengan tujuan utama untuk mengetahui keadaan organisasi tersebut secara lebih komprehensif. (Fahmi, 2014:252) Analisis SWOT didasarkan pada kesesuaian antara sumber daya internal dengan situasi eksternal perusahaan.

\section{Instrumen Penelitian}

Dalam penelitian kualitatif, yang menjadi instrumen penelitian atau alat penelitian adalah peneliti itu sendiri. (Sugiyono, 2009:231) Selain peneliti sebagai instrumen penelitian, pada penelitian ini juga dilengkapi dengan instrumen penelitian lain seperti, voice record untuk merekam segala bentuk wawancara yang dilakukan untuk memperoleh informasi atau data penelitian secara efektif dan efisien. Kemudian kamera yaitu instrumen yang digunakan untuk merekam aktivitas di dalam Kersan Art Studio visual dengan wujud akhir foto. Data ini akan digunakan untuk melengkapi hasil penelitian. 


\section{Tinjauan Teoritis}

1. Manajemen Strategi

Manajemen strategi adalah serangkaian keputusan dan tindakan manajerial yang menentukan kinerja perusahaan dalam jangka panjang, meliputi pengamatan lingkungan, formulasi strategi (perumusan strategi atau perencanaan jangka panjang), implementasi strategi, evaluasi serta pengendalian. Manajemen strategi menekankan pada pengamatan lingkungan dan evaluasi peluang dan ancaman dengan melihat kelemahan dan kekuatan perusahaan. (Wheelen \& L, 2009:4) Manajemen strategi merupakan upaya untuk mengelola strategi suatu bisnis agar tercapai tujuan bisnis. Pengelolaan strategi mencangkup, formulasi, implementasi, serta evaluasi dan pengendalian strategi. (Reksohadiprodjo, 2003:1)

\section{Perumusan Strategi}

Perumusan strategi adalah pengembangan rencana jangka panjang untuk manajemen efektif dari kesempatan dan ancaman lingkungan, dilihat dari kekuatan dan kelemahan perusahaan. Perumusan strategi meliputi, menentukan visi dan misi perusahaan, menentukan tujuan-tujuan yang dicapai, pengembangan strategi, dan penetapan pedoman kebijakan. (Huger \& L, 2009:12) Perumusan strategi dilakukan melalui ; analisis lingkungan eksternal dan internal, kemudian perumusan strategi (misi, tujuan, strategi, dan kebijakan).

\section{Analisis SWOT}

SWOT adalah singkatan $\quad \mathrm{d}$ a r i Strengths (kekuatan), Weaknesses (kelemahan), Opportunities (peluang), Threats (ancaman), dimana SWOT ini dijadikan sebagai suatu model dalam menganalisis suatu organisasi yang berorientasi profit dan non-profit dengan tujuan utama untuk mengetahui keadaan organisasi tersebut secara lebih komprehensif. (Fahmi, 2014:252) Analisis SWOT adalah suatu alat perencanaan strategi yang penting untuk membantu perencanaan dengan membandingkan kekuatan dan kelemahan internal perusahaan dengan peluang dan ancaman dari eksternal. (Wanti \& D.D. Rahayu, 2014) Analisis SWOT didasarkan pada kesesuaian antara sumber daya internal dengan situasi eksternal perusahaan. Untuk menganalisis secara lebih dalam tentang SWOT maka perlu dilihat faktor internal dan eksternal sebagai bagian penting dalam analisis SWOT, yaitu :

a. Faktor Internal

Faktor ini mempengaruhi terbentuknya kekuatan (strengths) dan kelemahan (weaknesses), dimana faktor ini menyangkut dengan kondisi yang terjadi dalam perusahaan, sertaikutmempengaruhi terbentuknya pembuatan keputusan perusahaan. Faktor internal ini meliputi semua manajemen fungsional : pemasaran, keuangan, operasional, sumber daya manusia, penelitian dan pengembangan, sistem informasi manajemen dan budaya perusahaan. (Fahmi, 2014:260)

b. Faktor Ekternal

Faktor Eksternal ini mempengaruhi terbentuknya peluang (oppourtunities) dan ancaman (threats), dimana faktor ini menyangkut kondisi-kondisi yang terjadi di luar perusahaan yang mempengaruhi dalam pembuatan keputusan perusahaan. Faktor ini mencangkup lingkungan industri dan lingkungan bisnis makro, ekonomi, politik, teknologi, dan sosial budaya. Dalam proses analisis SWOT menggunakan standar pengukuran yang nantinya akan dibobotkan oleh responden.. Hasil dari pembobotan tersebut merupakan angka yang akan diidentifikasi menjadi analisis internal dan eksternal yang akan dipertajam dengan adanya matrik IFAS (Internal Factor Analysis Summary) dan EFAS (External Factor Analysis Summary). Selanjutnya hasil dari pembobotan matrik IFAS dan EFAS kemudian di analisis dengan Kuadran SWOT. Terdapat mekanisme dan syarat pengukuran dalam perancangan instrumen penelitian, yaitu : 


\begin{tabular}{|c|c|c|c|}
\hline $\begin{array}{c}\text { Faktor-faktor } \\
\text { Strategi Internal }\end{array}$ & Bobot & Rating & $\begin{array}{c}\text { Bobot } x \\
\text { Rating }\end{array}$ \\
\hline Kekuatan: & $x$ & $x$ & $x$ \\
\hline Kelemahan : & $x$ & $x$ & $x$ \\
\hline \multicolumn{4}{|l|}{ Total : } \\
\hline $\begin{array}{c}\text { Faktor-faktor } \\
\text { Strategi Eksternal }\end{array}$ & Bobot & Rating & $\begin{array}{c}\text { Bobot } \mathrm{x} \\
\text { Rating }\end{array}$ \\
\hline Peluang : & $\mathrm{x}$ & $x$ & $x$ \\
\hline Ancaman : & $x$ & $x$ & $x$ \\
\hline Total : & & & \\
\hline
\end{tabular}

Tabel 1. dan Tabel 2. IFAS (Internall Factor Analysis Summary). (Rangkuty, 2004:24)

\section{Pemberian Bobot Skor}

Perhitungan pembobotan skor dapat dirumuskan sebagai berikut :

Bobot $=\frac{\text { Skor }}{\text { Total Skor }} \times 1$

Dimana :

- Skor adalah penilaian dari faktor strategis perusahaan

- Bobot adalah jumlah skor dari faktor strategis perusahaan

- Total skor adalah jumlah dari semua faktor

Jumlah semua bobot tidak boleh melebihi skor total 1, 00 (Rangkuty, 2004)

\section{Pemberian Rating}

Tahap ini bertujuan untuk mengetahui ke-efektifan formulasi strategi yang telah dilakukan untuk merespon faktor-faktor strategis yang ada. Pemberian peringkat dengan skala 1 sampai 4 untuk masing-masing faktor.

\section{Lingkungan Internal}

Kekuatan :

Rating 4 = Sangat Kuat

Rating 3 = Kuat

Rating 2 = Lemah

Rating 1 = Sangat Lemah
Kelemahan :

Rating 4 = Sangat Lemah

Rating $3=$ Lemah

Rating 2 = Kuat

Rating 1 = Sangat Kuat

\section{Lingkungan Eksternal}

Peluang :

Rating 4 = Sangat Kuat

Rating 3 = Kuat

Rating 2 = Lemah

Rating 1 = Sangat Lemah

Ancaman :

Rating 4 = Sangat Lemah

Rating 3 = Lemah

Rating 2 = Kuat

Rating 1 = Sangat Kuat

\section{Perkalian Bobot dan Peringkat}

Pada tahapan ini, mengalikan bobot dengan rating dari masing-masing faktor untuk mendapatkan nilai skor setiap faktor. Nilai skor setiap faktor kemudian dijumlahkan untuk memperoleh total nilai skor. Total nilai skor dari Matrik IFAS dan Matrik EFAS berada pada kisaran tertinggi $(4,0)$ hingga nilai terendah $(1,0)$ dengan nilai rata-rata adalah $(2,5)$. Jika nilai berada di bawah ratarata $(2,5)$ mengidentifikasi bahwa Kersan Art Studio kurang merespon faktor eksternal dan lemah pada faktor internal. Sementara jika nilainya berada di atas nilai rata-rata 2,5 mengidentifikasi bahwa Kersan Art Studio merespon faktor eksternal dengan baik dan kuat pada faktor internal.

\section{Tahap Pencocokan}

1. Diagram Analisis Kuadran SWOT

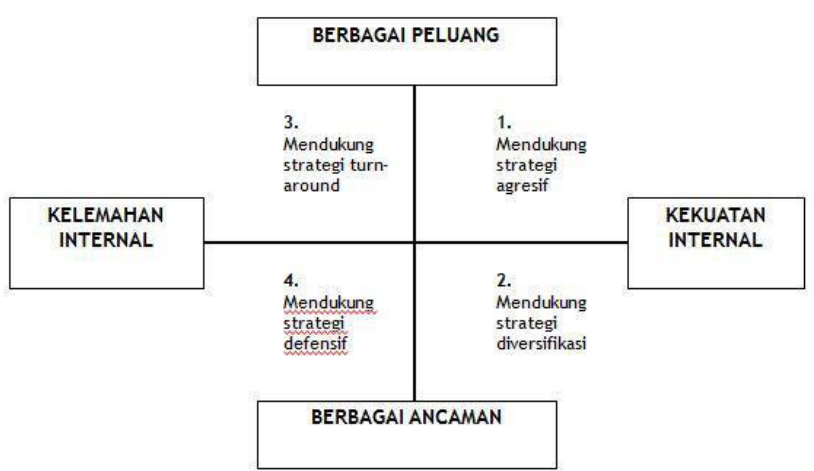

Gambar 1. Kuadran Analisis SWOT. (Rangkuty, 2004)

1. Matrik SWOT

Selanjutnya pada perumusan strategi, hasil dari proses pembobotan matrik IFAS dan EFAS kuesioner SWOT pada masingmasing variabel, akan dilakukan interaksi kombinasi dan strategi yang meliputi kombinasi internal dan eksternal terdiri dari : 
a. Strategi SO, strategi ini dibuat berdasarkan jalan pikiran perusahaan, yaitu dengan memanfaatkan seluruh kekuatan untuk merebut dan memanfaatkan peluang sebesar-besarnya.

b. Strategi ST, Ini adalah strategi dalam menggunakan kekuatan yang dimiliki perusahaan untuk mengatasi ancaman.

c. Strategi WO, strategi ini ditetapkan berdasarkan pemanfaatan peluang yang ada dengan cara meminimalkan kelemahan yang ada.

d. Strategi WT, strategi ini berdasarkan pada kegiatan yang bersifat defensif dan berusaha meminimalkan kelemahan yang ada serta menghindari ancaman. (Rangkuty, 2004:31-32)

\section{Tahap Penentuan Keputusan Strategi}

Pada tahap pengambilan keputusan dilakukan dengan menggunakan hasil strategi - strategi yang diperoleh dari kuadran analisis dan matrik SWOT. Nilai yang dihasilkan dari proses pengukuran pada tahap tersebut akan menghasilkan arah kebijakan strategi yang disarankan. Untuk mendukung implementasi strategi yang sesuai berdasarkan faktor kekuatan, kelemahan, peluang dan ancaman, dibutuhkan kecermatan dalam mengkorelasikan hubungan antara indikator yang telah ditentukan.

\section{Hasil Dan Pembahasan \\ Hasil Penelitian}

a. Sejarah Kersan Art Studio

Pada tahun 2009, Kersan Art Studio didirikan oleh Lenny Ratnasari Weichert yang merupakan seniman yang berbasis di Jakarta, Indonesia. Kersan Art Studio terletak di Jln. AS. Samawaat no 154, Dusun Kersan, Tirtonirmolo, Kasihan, Bantul, Daerah Istimewa Yogyakarta. Sejarah ruang yang saat ini menjadi Kersan Art Studio awalnya didirikan oleh komunitas seni Kua Etnika pada tahun 1997 sebagai studio di bidang interaksi musik, penyair dan teater. Pada tahun 2008 bangunan studio dialihkan kepemilikannya kepada Lenny Ratnasari.

Awalnya bangunan tersebut dijadikan tempat tinggal, tempat penyimpanan karya dan studio pribadi selama Lenny berada di Yogyakarta. Setelah itu dengan adanya permintaan serta inisiatif pihak luar untuk menggunakan ruang tersebut untuk ruang seni terbuka, akhirnya ruang tersebut dibuka untuk publik. Kelayakan ruang untuk menjadi ruang interaksi antara seni dengan publik merupakan latar belakang bagaimana

\begin{tabular}{|c|c|c|}
\hline IFAS & $\begin{array}{l}\text { Strengths }(\mathbf{S}) \\
\text { Tentukan 5-10 } \\
\text { Faktor-faktor } \\
\text { Kekuatan } \\
\text { Internal }\end{array}$ & $\begin{array}{l}\text { Weaknesses }(\mathrm{W}) \\
\text { Tentukan } 5-10 \\
\text { Faktor-faktor } \\
\text { Kelemahan Internal }\end{array}$ \\
\hline $\begin{array}{l}\text { Opportunies }(\mathbf{O}) \\
\text { Tentukan 5-10 } \\
\text { Faktor-faktor } \\
\text { Peluang Eksternal }\end{array}$ & $\begin{array}{l}\text { Strategi SO } \\
\text { Ciptakan strategi yang } \\
\text { menggunakan kekuatan } \\
\text { untuk memanfaatkan } \\
\text { peluang }\end{array}$ & $\begin{array}{l}\text { Strategi WO } \\
\text { Ciptakan strategi yang } \\
\text { meminimalkan } \\
\text { kelemahan untuk } \\
\text { memanfaatkan peluang }\end{array}$ \\
\hline $\begin{array}{c}\text { Treaths }(\mathbf{T}) \\
\text { Tentukan 5-10 } \\
\text { Faktor-faktor } \\
\text { Ancaman } \\
\text { Eksternal }\end{array}$ & $\begin{array}{l}\text { Strategi ST } \\
\text { Ciptakan strategi yang } \\
\text { menggunakan kekuatan } \\
\text { untuk mengatasi ancaman }\end{array}$ & $\begin{array}{l}\text { Strategi WT } \\
\text { Ciptakan strategi yang } \\
\text { meminimalkan } \\
\text { kelemahan dan } \\
\text { menghindari ancaman }\end{array}$ \\
\hline
\end{tabular}

Tabel 3. Matrik SWOT. (Rangkuty, 2004) 
Kersan Art Studio lahir di dunia seni rupa saat ini. Bermula dari ruang studio dan tempat tinggal, kemudian berubah menjadi ruang seni terbuka dan pada Tanggal 14 Februari tahun 2009 Kersan Art Studio diresmikan.

Pemilihan nama "Kersan Art Studio" dikarenakan fungsi awal adalah studio kemudian dibuka untuk ruang pameran, sedangkan pemilihan nama "Kersan" karena terletak di dusun Kersan, akhirnya dipilihlah nama Kersan Art Studio. Kersan Art Studio berperan sebagai 'studio', dalam hal ini lebih menekankan pada proses dan ruang seni yang terbuka dimana Kersan Art Studio menjadi ruang komunikasi antara seniman, kurator, penulis, akademisi dan juga bekerja sama dengan institusi lain. Kersan Art Studio berfokus pada pameran, proyek seni, musik, presentasi, pertukaran seniman dan residensi. Kersan Art Studio adalah salah satu wujud dedikasi Lenny Ratnasari Weichert bagi perkembangan ruang seni khususnya di Yogyakarta.

b. Visi dan Misi

Visi sebuah organisasi merupakan target yang ingin dicapai oleh organisasi tersebut. Berdasarkan hasil observasi dan wawancara Kersan Art Studio belum mempunyai visi secara tertulis. Visi yang dimiliki juga belum memiliki jangka waktu penyelesaiannya. Berdasarkan hasil wawancara visi yang dimiliki oleh Kersan Art Studio saat ini adalah :

- Menjadi lembaga yang berkontribusi bagi perkembangan seni rupa di Indonesia khususnya di Yogyakarta.

c. Harapan Pemangku Kepentingan

Stakeholder adalah pihak-pihak yang terkait dan berkepentingan terhadap organisasi. Pada pengelolaan Kersan Art Studio ini peneliti mengidentifikasi stakeholder yang dimiliki oleh Kersan Studio adalah: Pemilik Kersan Art Studio yaitu Lenny Ratnasari, Ketua Pembina Yayasan Seni Kersan Indonesia

Prof. M. Dwi Marianto, dan lembaga Asian Leadersip Centre selaku sponsor tetap dari Kersan Art Studio.

Pada pengelolaan Kersan Art Studio peran pengambil keputusan terkait dengan gagasan dan masalah teknis pengelolaan organisasi menjadi wewenang Lenny Ratnasari sebagai pemilik Kersan Art Studio. Ketua Pembina Yayasan Seni Kersan Indonesia juga memiliki andil dalam pengambilan keputusan yang dibuat oleh pemilik terutama pada hal-hal yang berkaitan dengan Yayasan, serta Lembaga Asean Leadership Center yang bertindak sebagai penyandang dana bagi Kersan Art Studio.

d. Analisis Lingkungan

1) Analisis Lingkungan Internal

b) Kekuatan

- Memiliki jaringan kerjasama yang luas baik lokal maupun internasional.

- Memiliki sponsor tetap.

- Berbadan hukum dan memiliki yayasan sendiri.

- Sebagai ruang seni, Kersan Art Studio sudah memiliki ciri khas tersendiri di dunia seni rupa.

- Pemilik galeri menggunakan jaringan ke-senimanannya.

- Memiliki program unggulan yaitu residensi seniman mancanegara.

c) Kelemahan

- Kurangnya SDM yang dimiliki oleh Kersan Art Studio.

- Kurangnya publikasi acara.

- Keterbatasan ruang pamer

- Kurangnya pengelolaan arsip yang dimiliki

- Belum memiliki bangunan tetap

- Visi dan misi belum didefinisikan secara jelas dan tertulis

2) Analisis Lingkungan Eksternal

a) Peluang

- Yogyakarta sebagai Kota Seni

- MEA (Masyarakat Ekonomi ASEAN)

- Perkembangan teknologi yang memudahkan akses Kersan Art Studio

- Semakin banyaknya dana sosial untuk pengembangan kesenian khususnya di Yogyakarta.

- Lokasi Kersan Art Studio dekat dengan Kampus Seni ISI Yogyakarta 
- Daerah Kersan dekat dengan tempat domisili para seniman.

b) Ancaman

- Galeri-galeri seni di sekitar kawasan Kersan Art Studio

- Perkembangan teknologi yang membuat seniman sekarang tidak memerlukan informasi dari lembaga untuk melakukan residensi ke luar negeri.

- Kebijakan pemerintah tentang keperluan ke luar negeri yang bisa berubah-ubah.

- Seniman-seniman mulai membuka studio pribadinya seperti halnya Kersan Art Studio.

- Kurangnya apresiasi masyarakat sekitar terhadap programprogram yang dimiliki.ersepsi tentang Kersan Art Studio.

e. Tahap Pencocokan

Pada koordinat kuadran analisis SWOT diatas menunjukkan bahwa pengeloaan ruang seni Kersan Art Studio berada pada kuadaran I dengan arah strategi agresif. Pada kuadran tersebut pengelolaan ruang seni Kersan Art Studio berada pada posisi yang strategis dan sangat menguntungkan, Kersan Art Studio memiliki peluang dan kekuatan sehingga dapat melakukan percepatan pengembangan dengan memaksimalkan posisi peluang dan kekuatan untuk meminimalisir kelemahan dan ancaman.

Setelah teridentifikasi letak titik koordinat pengelolaan ruang seni Kersan Art Studio, maka langkah berikutnya adalah menentukan rumusan strategi pada matrik SWOT. Matrik SWOT merumuskan strategi yang relevan untuk diimplementasikan sebagai salah satu solusi dalam bentuk menggabungkan kekuatan dan peluang sebagai daya dukung pengelolaan yang optimal. Proses tersebut mampu menekan tingkat ancaman dan meminimalisir kelemahan yang berpotensi sebagai penghambat keberhasilan mencapai tujuan dan visi misi yang hendak dicapai.

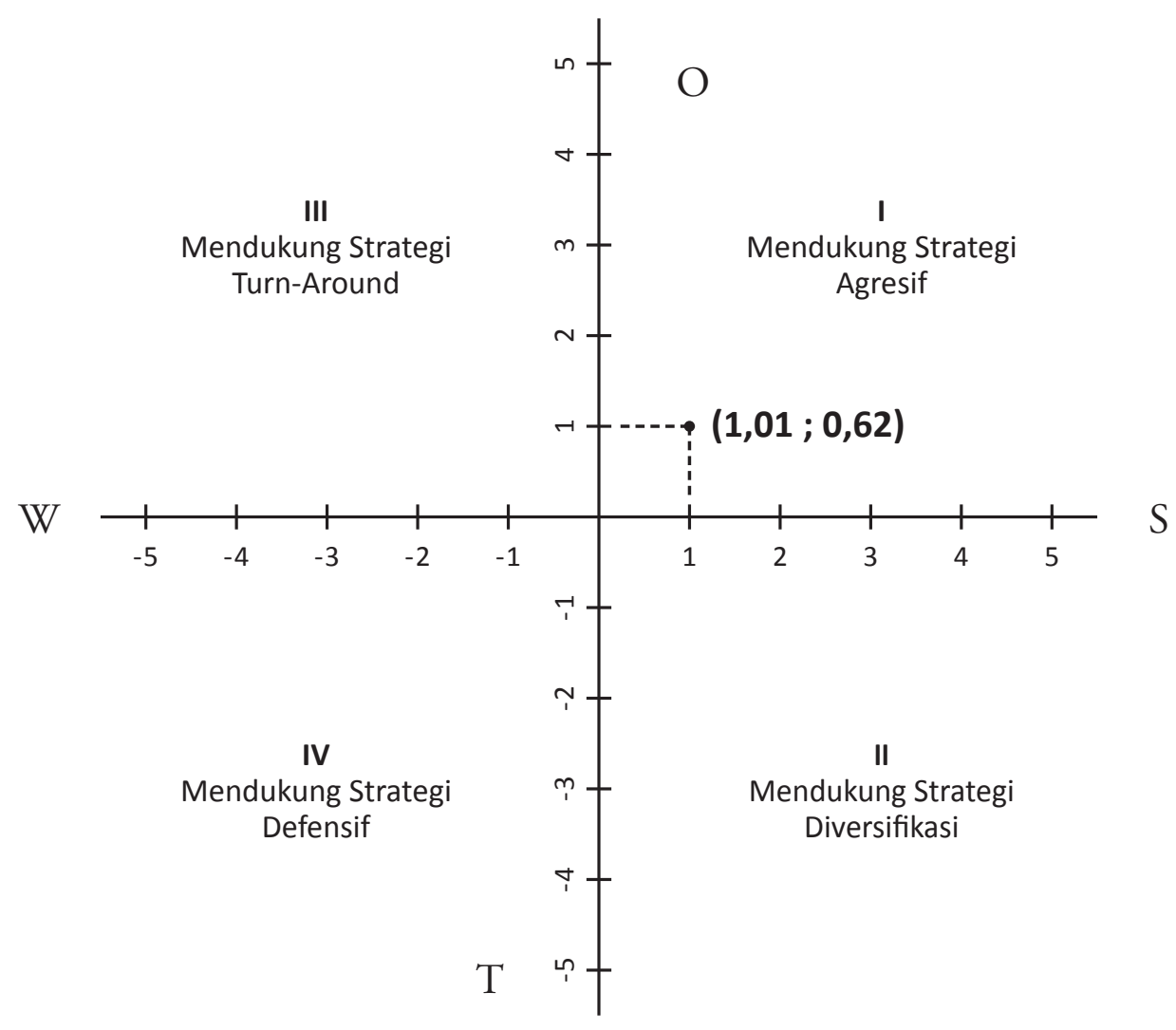

Gambar 2. Hasil Kuadran Analisis SWOT (Rangkuty, 2004) 


\begin{tabular}{|c|c|c|}
\hline EFAS & $\begin{array}{l}\quad \text { STRENGTHS (S) } \\
\text { · } \text { Memiliki jaringan kerjasama yang luas } \\
\text { baik Lokal maupun Internasional } \\
\text { · } \text { Memiliki sponsor tetap } \\
\text { · } \text { Berbadan Hukum dan Memiliki } \\
\text { Yayasan sendiri } \\
\text { · Sebagai ruang seni, Kersan Art Studio } \\
\text { sudah memiliki ciri khas tersendiri di } \\
\text { dunia seni rupa } \\
\text { · Pemilik galeri menggunakan jaringan } \\
\text { ke-senimanannya dengan memperluas } \\
\text { dukungan dan kerjasama bagi Kersan } \\
\text { Art Studio } \\
\text { Memiliki program unggulan yaitu } \\
\text { pertukaran seniman dan residensi }\end{array}$ & $\begin{array}{l}\quad \text { WEAKNESSES (W) } \\
\text { · Kurangnya SDM yang dimiliki oleh } \\
\text { Kersan Art Studio } \\
\text { · Kurangnya publikasi acara } \\
\text { · Keterbatasan ruang pamer, hanya } \\
\text { terdapat } 1 \text { ruang pamer dengan } \\
\text { ukuran kecil } \\
\text { · Kurangnya pengelolaan arsip yang } \\
\text { dimiliki } \\
\text { - Belum memiliki bangunan tetap } \\
\text { · Visi dan misi belum didefinisikan } \\
\text { secara jelas dan tertulis }\end{array}$ \\
\hline 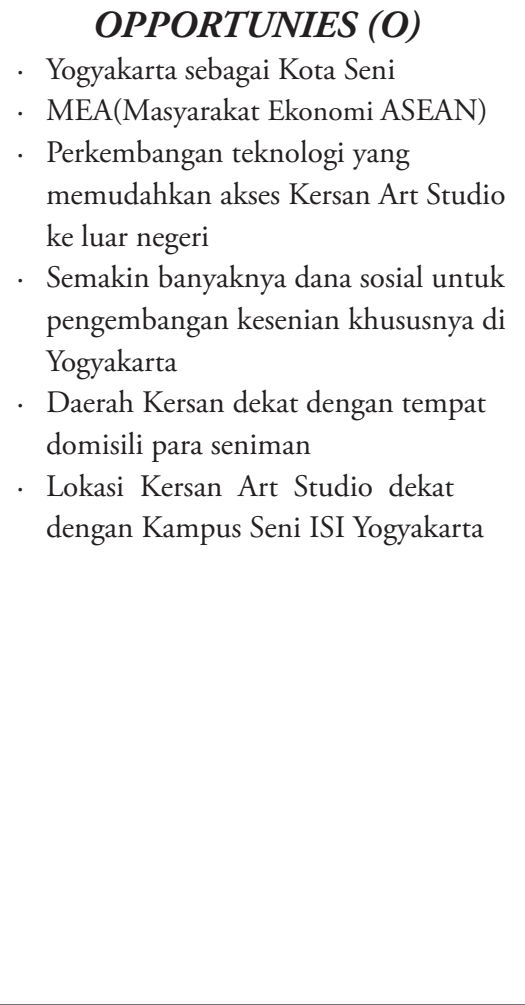 & 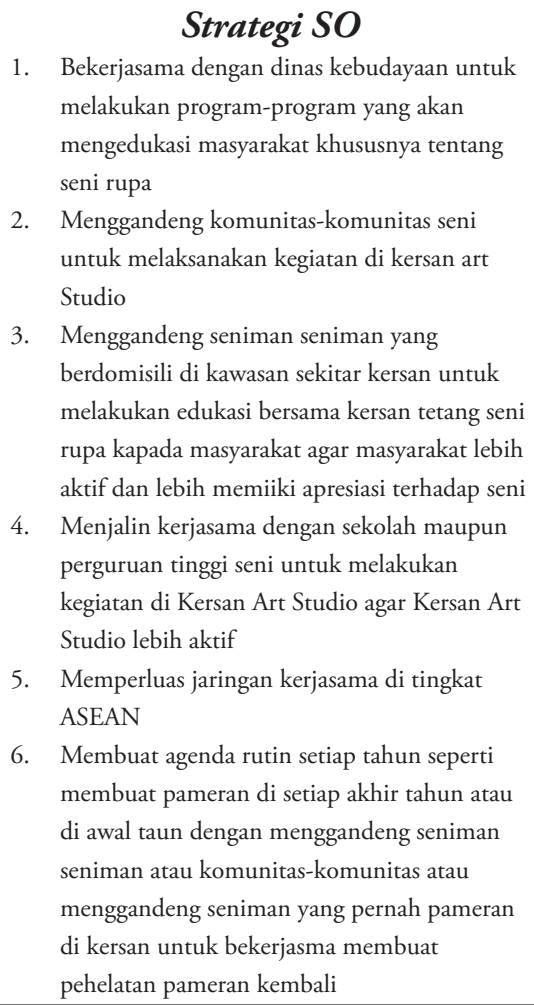 & $\begin{array}{l}\text { Strategi WO } \\
\text { 7) Membuat arsip berupa video terutama } \\
\text { untuk seniman residensi dari awal } \\
\text { residensi hingga penyelenggaran } \\
\text { pameran agar seniman lebih tau tentang } \\
\text { perkembangannya selama melaksanakan } \\
\text { residensi di kersan } \\
\text { 8) Membuat sebuah video untuk } \\
\text { mempresentasikan prosose berkarya } \\
\text { seniman residensi. } \\
\text { Memanfaatkan media sosial untuk } \\
\text { melakukan promosi setiap prgram secara } \\
\text { aktif bukan hanya saat memiliki agenda } \\
\text { kegiatan saja tetapi aktif menjelaskan } \\
\text { tentang program-program yang dimiliki } \\
\text { agar lebih di ketahui oleh publik. } \\
\text { Memanfaatkan peran teknologi informasi } \\
\text { sebagai media promosi, soasaialisasi edukasi } \\
\text { dan menghimpun referensi } \\
\text { 10) Membagun data base yang rapi dan } \\
\text { komunikatif kepada para stakeholder serta } \\
\text { untuk memudahkan pencarian dana }\end{array}$ \\
\hline $\begin{array}{l}\text { THREATS (T) } \\
\text { · Galeri-galeri seni di sekitar kawasan Kersan } \\
\text { Art Studio } \\
\text { · } \text { Perkembangan teknologi yang membuat } \\
\text { seniman sekarang tidak memerlukan } \\
\text { informasi dari lembaga untuk melakukan } \\
\text { residensi ke luar negeri } \\
\text { - Kebijakan pemerintah tentang keperluan } \\
\text { ke luar negeri seperti keperluan di bagian } \\
\text { imigrasi, masalah pastpor, visa dsb. yang } \\
\text { bisa berubah-ubah. } \\
\text { - Seniman - seniman mulai membuka studio } \\
\text { pribadinya seperti halnya Kersan Art Studio } \\
\text {. Kurangnya apresiasi masyarakat sekitar } \\
\text { terhadap program-program yang dimiliki } \\
\text {. Asumsi terhadap Kersan Art Studio }\end{array}$ & $\begin{array}{l}\text { Strategi ST } \\
\text { 11) Memaksimalkan peran yayasan dalam } \\
\text { pencarian dukungan untuk program serta } \\
\text { mempersaiapkan keperluan residensi secara } \\
\text { legal } \\
\text { 12) Merancang program yang lebih menarik } \\
\text { lagi } \\
\text { 13) Membuat acara pendukung terutama saat } \\
\text { pembukaan pameran agar lebih menarik } \\
\text { masa datang melihat pameran } \\
\text { 14) Memperluas progam bukan hanya di } \\
\text { tingkat seni rupa tapi di tingkat seni } \\
\text { pertunjukan dan lainnya }\end{array}$ & $\begin{array}{l}\text { Strategi WT } \\
\text { 15) Mematangkan visi dan misi oragnisasi agara } \\
\text { lebih jelas dalam proses pencapaiannya. } \\
\text { 16) Melibatkan tim kerja ahli terutama di } \\
\text { 17) bagian pendokumentasian dan pengelolaan } \\
\text { arsip serta menambah sumber daya manusia } \\
\text { dengan kemampuan bahas asing yang bagus } \\
\text { 18) Menjadikan ruang seni lainnya sebagai } \\
\text { bagian dari dinamika dan studi banding } \\
\text { untuk menjadi sebuah ruang seni atau } \\
\text { lembaga seni yang lebih baik } \\
\text { 19) Mengoptimalkan program-program saat ini } \\
\text { dapat terlaksana dengan baik } \\
\text { 20) Membuat katalog untuk setiap pameran } \\
\text { dan di jadikan sebagai arsip dan bukti } \\
\text { bahwa pameran tersebut pernah } \\
\text { terselenggara di kersan art studio }\end{array}$ \\
\hline
\end{tabular}

Tabel 4. Matrik SWOT 
f. Tahap Keputusan

Tahap keputusan berdasarkan dua formulasi di atas, maka diperoleh hasil bahwa pengelolaan ruang seni Kersan Art Studio saat ini berada pada kuadran I. Pada kuadran tersebut pengelolaan ruang seni Kersan Art Studio berada pada posisi yang strategis dan sangat menguntungkan, Kersan Art Studio memiliki peluang dan kekuatan sehingga dapat melakukan percepatan pengembangan dengan memaksimalkan posisi peluang dan kekuatan untuk meminimalisir kelemahan dan ancaman.

Strategi yang disarankan dalam posisi tersebut adalah strategi $\mathrm{SO}$ yaitu strategi dengan memanfaatkan seluruh kekuatan untuk merebut dan memanfaatkan peluang sebesar-besarnya. Selain itu pada tingkat kuadran I ini juga memungkinkan Kersan Art Studio untuk menggunakan arah kebijakan startegi agresif.

\section{Pembahasan}

\section{Berdasarkan Kuadran Analisis SWOT}

Pada kuadran analisis SWOT, faktor Internal berada pada titik koordinat 1,01 dan faktor eksternal pada koordinat 0,62 . Sehingga pengelolaan ruang seni Kersan Art Studio berdasarkan hasil tahap pencocokan yang dilakukan dengan menentukan posisi pengelolaan objek pada Kuadran Analisis SWOT, berada pada kuadaran I dengan arah strategi agresif. Pada posisi tersebut pengelolaan Kersan Art Studio sebagai sebuah ruang seni yang berada di Yogyakarta memiliki potensi yang tinggi.

Strategi yang harus diterapkan dalam kondisi ini adalah mendukung kebijakan pertumbuhan yang agresif (Growth oriented strategy). Strategi Pertumbuhan (Growth Strategy) adalah strategi untuk mencapai pertumbuhan, baik dalam penjualan, aset, profit, atau kombinasi dari ketiganya. Hal ini dapat dicapai dengan menurunkan harga, mengembangkan produk baru, menambah kualitas produk atau jasa, atau meningkatkan akses ke pasar yang lebih luas bagi Kersan Art Studio.

Dengan berbagai faktor internal dan eksternal yang dimiliki oleh Kersan Art Studio memungkinkan Kersan untuk lebih berkembang menjadi sebuah ruang seni yang berdampak di dunia seni rupa Indonesia, khususnya di Yogyakarta. Langkah strategi yang dapat dicapai untuk mendukung pencapaian tersebut adalah :

\section{a. Pengembangan Pasar}

Pengembangan pasar meliputi pengenalan produk atau jasa yang ada saat ini ke wilayah-wilayah geografis yang baru. (Rangkuty, 2004:258) Pasar memiliki keterkaitan yang sangat kuat terhadap keberadaan dan keberhasilan sebuah ruang seni. Pada pegelolaan ruag seni Kersan Art Studio.

Beberapa langkah strategis yang dapat diimplementasikan melalui strategi adalah :

1) Memperluas jaringan kerjasama di tingkat ASEAN.

2) Bekerjasama dengan Dinas Kebudayaan untuk melakukan program-program yang akan mengedukasi masyarakat khususnya tentang seni rupa.

3) Menggandeng komunitas-komunitas seni untuk melaksanakan kegiatan di Kersan Art Studio seperti diskusi seni dan workshop.

4) Menggandeng seniman-seniman yang berdomisili di kawasan sekitar Kersan untuk melakukan edukasi tentang seni rupa kepada masyarakat agar masyarakat lebih aktif dan lebih memiliki apresiasi terhadap seni.

5) Menjalin kerjasama dengan sekolah maupun perguruan tinggi seni untuk melakukan kegiatan di Kersan Art Studio agar Kersan Art Studio lebih aktif.

\section{b. Intigrasi Horizontal}

Pada pengelolaan ruang seni Kersan Art Studio proses penerapan strategi 
horizontal diwujudkan dalam bentuk memperluas operasi antar penyelenggara dengan penyelenggara lain dalam lingkup operasi yang berbeda. (David, 2006: 256) Membuat agenda rutin setiap tahun seperti membuat pameran di setiap akhir tahun atau di awal tahun dengan menggandeng seniman seniman atau komunitas-komunitas atau menggandeng seniman yang pernah pameran di Kersan untuk bekerjasama membuat perhelatan pameran kembali.

1) Melibatkan tim kerja ahli terutama di bagian pendokumentasian dan pengelolaan arsip serta menambah sumber daya manusia dengan kemampuan bahas asing yang baik.

2) Memaksimalkan peran yayasan dalam pencarian dukungan untuk program serta mempersiapkan keperluan residensi secara legal.

\section{c. Integrasi ke Belakang}

Integrasi ke belakang adalah sebuah strategi yang mengupayakan kepemilikan atau kendali yang lebih besar atas pemasok perusahaan. (David, 2006:255) Proses penerapan integrasi ke belakang pada pengelolaan ruang seni Kersan Art Studio diwujudkan dengan cara meningkatkan jangkauan relasi terhadap keberadaan para stakeholder.

Membangun data base yang rapi dan komunikatif kepada para stakeholder untuk memudahkan pencarian dana.

\section{Berdasarakan Matrik SWOT}

Selain itu, Kuadran Analisis SWOT pengelolaan ruang seni Kersan Art Studio berada pada posisi yang strategis dan sangat menguntungkan, Kersan memiliki peluang dan kekuatan sehingga dapat melakukan percepatan pengembangan dengan memaksimalkan posisi peluang dan kekuatan untuk meminimalisir kelemahan dan ancaman. Posisi tersebut mengarah pada startegi SO yaitu :

Strategi SO

a) Bekerjasama dengan Dinas Kebudayaan untuk melakukan program-program yang akan mengedukasi masyarakat khususnya tentang seni rupa.

b) Menggandeng komunitas-komunitas seni untuk melaksanakan kegiatan di Kersan

Art Studio seperti diskusi seni dan workshop.

c) Menggandeng seniman-seniman yang berdomisili di kawasan sekitar kersan untuk melakukan edukasi tentang seni rupa kepada masyarkat agar masyarakat lebih aktif dan lebih memiliki apresiasi terhadap seni.

d) Menjalin kerjasama dengan sekolah maupun perguruan tinggi seni untuk melakukan kegiatan di Kersan Art Studio agar Kersan Art Studio lebih aktif.

e) Memperluas jaringan kerjasama di tingkat ASEAN.

f) Membuat agenda rutin setiap tahun seperti membuat pameran di setiap akhir tahun atau di awal tahun dengan menggandeng seniman seniman atau komunitas-komunitas atau menggandeng seniman yang pernah pameran di kersan untuk bekerjasma membuat perhelatan pameran kembali.

\section{Kesimpulan dan Saran}

Sebagai sebuah ruang seni, Kersan Art Studio memiliki pengelolaan yang baik dalam segi manajemen. Program-program yang dimiliki selalu berjalan dengan lancar. Kersan juga telah memiliki program unggulan yaitu pertukaran dan residensi seniman. Sebagai sebuah lembaga seni, Kersan Art Studio telah mempersiapkan diri dengan mendirikan Yayasan Seni Kersan Indonesia untuk memenuhi kebutuhan akan praktik-praktik yang lebih luas seperti kebutuhankebutuhan tertentu yang mengharuskan Kersan Art Studio mempunyai lembaga hukum atau lembaga resmi yang bisa dipertanggung jawabkan atas keberadaannya untuk melakukan kerjasama, menjalin hubungan di tingkat internasional seperti mengundang seniman atau bekerjasama dengan lembaga luar dan berhubungan dengan sponsor.

Saat ini Kersan Art Studio belum memiliki rencana strategi untuk perkembangan kedepannya. Melihat banyaknya galeri dan ruang 
seni yang gagal mempertahankan eksistensinya di tengah dunia seni rupa, salah satu penyebabnya dikarenakan tidak adanya rencana atau strategi jangka panjang untuk mempertahankan keberlangsungan lembaga tersebut. Sangat penting bagi Kersan Art Studio untuk memiliki perencanaan strategi jangka panjang agar tetap mampu bertahan di dunia seni rupa.

Hasil penelitian ini merumuskan perencanaan strategi untuk Kersan Art Studio. Berdasarkan hasil analisis lingkungan internal dan eksternal yang meliputi kekuatan, kelemahan, peluang, dan ancaman yang dinilai menggunakan pembobotan matrik IFAS (Internal Factor Analysis Summary) dan EFAS

(External Factor Analysis Summary), mendudukkan posisi pengelolaan Kersan Art Studio saat ini berada pada kuadran I berdasarkan hasil analisis Kuadaran SWOT dengan arah kebijakan strategi agresif. Strategi yang harus diterapkan dalam kondisi ini adalah mendukung kebijakan pertumbuhan yang agresif (Growth Oriented Strategy). Selain itu, Kuadran Analisis SWOT pengelolaan ruang seni Kersan Art Studio berada pada posisi yang strategis dan sangat menguntungkan, Kersan memiliki peluang dan kekuatan sehingga dapat melakukan percepatan pengembangan dengan memaksimalkan posisi peluang dan kekuatan untuk meminimalisir kelemahan dan ancaman. Posisi tersebut mengarah pada strategi SO. Dengan berbagai faktor internal dan eksternal yang dimiliki oleh Kersan Art Studio memungkinkan Kersan untuk lebih berkembang menjadi sebuah ruang seni yang berdampak di dunia seni rupa Indonesia, khususnya di Yogyakarta

\section{Saran}

1. Saran untuk pengelola

a. Pengelolaan Kersan Art Studio mulai melihat faktor internal dan eksternal yang dimiliki yaitu menggunakan kekuatan untuk meraih peluang yang ada, menggunakan kekuatan untuk meminimalisir kelemahan dan ancaman.

b. Melihat dari hasil penelitian, dengan adanya dua pengelola yang aktif disarankan bagi kersan Art Studio untuk menambah sumber daya pengelola agar program-program yang berskala lebih besar mudah dijalankan dengan adanya sumber daya manusia tambahan.

c. Promosi yang dilakukan di Kersan Art Studio memungkinkan untuk menambah kapasitas melalui media cetak seperti undangan, poster, dan spanduk, karena dalam lingkup seni rupa bentuk promosi secara fisik lebih mampu menarik perhatian untuk datang ke pameran.

2. Saran untuk penelitian lebih lanjut

Penelitian ini terbatas hanya pada perumusan strategi, belum sampai pada tahap implementasi dan evaluasi strategi. Oleh sebab itu, peneliti menyarankan untuk penelitian selanjutnya agar lebih mengkaji pada tahapan implementasi strategi dan evaluasi strategi yang digunakan dalam manajemen startegi pengelolaan ruang seni khususnya di Kersan Art Studio, sehingga dapat memberikan kontribusi dalam meningkatkan pengelolaan Kersan Art Studio. Serta dapat memberikan kontribusi positif bagi penelitian mengenai ruang seni yang terdapat di Indonesia.

\section{Daftar Pustaka}

David, F. R. (2006). Strategic Management, Concept and Case 10th ed. Jakarta: Salemba Empat.

Fahmi, I. (2014). Manajemen Strategi Teori dan Aplikasi. Bandung: Alfabeta.

Huger, J. D., \& L, T. W. (2009). Huger \& Thomas L Wheelen, Strategic Management 6th Edition atau Manajemen Strategis. Yogyakarta: Andi Offset.

Jusmani, D. S. (2014). "Studio, Agen, dan Infrastruktur Seni”, (naskah disajikan dalam pembicaraan pada diskusi panel dengan tema : Studio, Agen dan Infrastruktur Seni, pada rangkaian acara pameran Seni Rupa Fitur dan Figur.

Rangkuty, F. (2004). Analisis SWOT Teknik Membedah Kasus Bisnis Reorientasi Konsep Perencanaan Strategis untuk Menghadapi Abad 21. Jakarta: Gramedia Pustaka utama. Reksohadiprodjo, S. (2003). Manajemen Strategi Edisi 4. Yogyakarta: BPFE. 
Sucitra, I Arya. (2012). Ketika Seniman Membangun Galeri Kajian Manajemen Strategik Ruang Sangkring Art Space Yogyakarta. ORNAMEN, 9(2).

Sugiyono. (2009). Metode Penelitian Kuantitatif Kualitatif dan R \& D. Bandung: Alfabeta. Wanti, S. T., \& D.D. Rahayu. (2014). "Analisis Keunggulan Strategi Keunggulan bersaing dengan pendekatan analisis SWOT pada Spartan Gym Pekanbaru." JOM Fekon, 1(2). Yaniawati, R. I., \& Poppy, R. (2014). Metode Penelitaian Kuantitatif, Kualitatif dan Campuran untuk Manajemen. Bandung: Refika Aditama.

Zulnaidi. (2007). Metodologi Penelitian. Medan: Universitas Sumatera Utara. 